\title{
Diagnosis of soil fertility and banana crop nutrition in the state of Santa Catarina
}

\author{
Gelton Geraldo Fernandes Guimarães ${ }^{1} \&$ José Aridiano Lima de Deus $^{2}$
}

\begin{abstract}
Soil fertility and nutritional imbalance are among the main limitations in banana production. The present study aimed to diagnose soil fertility and nutrition of bananas trees cultivated in the state of Santa Catarina, southern Brazil. Leaf and soil samples were collected, and banana yield was quantified in 2018 and 2019 in 53 orchards in the regions of 'Vale do Itajai' and northern coast of Santa Catarina. Although orchards had satisfactory yield ( $42 \mathrm{t} / \mathrm{ha} /$ year), limitations related to soil fertility and banana crop nutrition were evident. The observed yield is $59.6 \%$ of its full potential. Liming is still recurrent, mainly before orchard establishment. Fertilizer application is widespread, but in many cases, doses are overestimated. $\mathrm{Ca}, \mathrm{Zn}, \mathrm{Cu}$, and $\mathrm{B}$ contents increased in leaves emitted in periods of higher soil water availability and higher temperatures. The results highlight the influence of weather conditions on the supply of these nutrients to banana plants. Nutritional factors are the main limiting factors in banana production in the state of Santa Catarina, compared to non-nutritional factors.
\end{abstract}

Index Terms: Fruit culture; banana production; banana crop nutrition; nutritional management.

\section{Diagnóstico da fertilidade do solo e nutrição de bananais no Estado de Santa Catarina}

Corresponding author: geltonguimaraes@epagri.sc.gov.br Received: September 25, 2020 Accepted: May 18, 2021

Copyright: All the contents of this journal, except where otherwise noted, is licensed under a Creative Commons Attribution License.
Resumo - A fertilidade do solo e o desequilíbrio nutricional estão entre as principais limitações na produção de banana. O presente estudo teve como objetivo diagnosticar a fertilidade do solo e a nutrição de bananais cultivadas no Estado de Santa Catarina, no Sul do Brasil. Foram realizadas coletas de folhas e de solo, e quantificada a produtividade da banana em 2018 e 2019, em 53 pomares da região do Vale do Itajaí e litoral norte de Santa Catarina. Embora os pomares apresentassem produtividade satisfatória (42 t/ha/ano), eram evidentes as limitações relacionadas à fertilidade do solo e à nutrição da bananeira. O rendimento observado é de 59,6\% de seu potencial total. A calagem ainda é recorrente, principalmente antes do estabelecimento do pomar. A aplicação de fertilizantes é generalizada, mas, em muitos casos, as doses são superestimadas. Os teores de $\mathrm{Ca}, \mathrm{Zn}, \mathrm{Cu}$ e B aumentaram nas folhas emitidas em períodos de maior disponibilidade de água no solo e em temperaturas mais altas. Os resultados evidenciam a influência das condições climáticas no fornecimento desses nutrientes às bananeiras. Fatores nutricionais são os principais limitantes da produtividade da banana em Santa Catarina, mais do que fatores não nutricionais.

Termos para indexação: Fruticultura; produção de banana; nutrição de bananeiras; manejo nutricional 


\section{Introduction}

Brazil is the world's fourth largest banana producer and fifth in harvested area, and in 2018, production reached 6.75 million tons (FAOSTAT, 2020). This result demonstrates its great international importance, highlighting the country as food producer and in food security. This prominent position is due to investment actions that the sector has received in recent decades, mainly related to the availability of genetic material, technologies in the production of quality seedlings, better cultural management practices before and after harvest, integrated pest, disease and weed management, adoption of irrigation and fertigation technologies, and improvement of the technical and organizational level of Brazilian banana growers (LICHTEMBERG; LICHTEMBERG, 2011). Despite advances related to this sector, banana productivity has stagnated in Brazil over the last 50 years, with average productivity close to $15 \mathrm{t}$ ha $^{-1}$ (DEUS et al., 2020).

The state of Santa Catarina stands out in the national banana production, being the fourth producer with the third highest productivity (CEPA, 2018). The state accounts for more than $10 \%$ of national production and $70 \%$ of all production in the southern region, producing around 719 thousand tons of fruits. Although productivity of $28.8 \mathrm{tha}^{-1}$ in Santa Catarina (predominantly from the Cavendish subgroup) is higher than the national average, the performance of banana cultivation in Santa Catarina is considered low, since the productive potential of these cultivars is much higher than that currently achieved.

Banana production in the state is concentrated in two main regions: Northern coast and 'Vale do Itajaí', accounting for $85 \%$, and the Southern coast for $15 \%$ of the state's total production (CEPA, 2018). The cultivation of banana 'Cavendish' subgroup (caturra) predominates in the state, with $85 \%$ of commercial production and the remainder is represented by banana from the 'Prata' subgroup. Despite the different edaphoclimatic conditions, fertilization is widespread among these regions, with overestimation and/or underestimation of doses applied in different areas. In addition, many banana growers do not adopt liming and fertilization recommendations proposed and established by the scientific community according to fertilization tables and manuals (DEUS et al., 2018; GUIMARÃES et al., 2020: LIMA NETO et al., 2020).

Large part of nutrients absorbed by banana trees during their development returns to the soil after the decomposition/mineralization of residues that are left in banana orchards. According to Hoffmann et al. (2010), for production of $24.8 \mathrm{t} \mathrm{ha}^{-1}$ of "Prata Anã" banana, $77 \%$ of the plant's accumulated biomass are deposited in the soil after fruit harvesting and most nutrients absorbed by the plant are returned to the soil on that occasion. However, this nutrient supply through biogeochemical cycling is often not accounted for in subsequent recommendations, which results in areas with excess nutrients, intensifying nutritional imbalances due to the absence of specific fertilization programs for banana production. This condition characterizes one of the main factors that predispose plants to infection by pathogens (ALVARES et al., 1981; SILVA and RODRIGUES, 2013; FREITAS et al., 2015).

The first step to establish action strategies related to soil fertility and nutrition of banana plantations in the state of Santa Catarina is based on identifying the main limitations and deficiencies that reduce production and relating them to the nutritional management adopted. For this, it is essential to carry out a diagnosis of the nutritional status of orchards in the main producing regions of the state. Thus, the aim of the present study was to diagnose the nutritional status of banana trees and the seasonal variation of the nutrient content in leaves and to identify the main nutritional limitations that reduce productivity and sustainability of banana production in the state of Santa Catarina.

\section{Material and methods}

The study was carried out in commercial banana orchards (Cavendish subgroup) that represent the conditions and management used by banana growers in Santa Catarina. Evaluation was carried out in the main banana-producing municipalities located in the regions of 'Vale do Itajaí' and Northern Coast of Santa Catarina, namely: Corupá, Luiz Alves, Massaranduba, Jaraguá do Sul, São João do Itaperiú, Schroeder and Balneário Piçarras (Figure 1). The accumulated precipitation and average air temperature in the region in the period from August 2018 to July 2019 are shown in Figure 2, according to Epagri/Ciram. The most frequent soil classes in the region are Argisols and Cambisols (EMBRAPA, 2004).

Soil and leaf sampling was carried out in 53 orchards from September 2018 to April 2019. With the help of Epagri researchers in each municipality, 15 simple soil samples were collected from each banana plantation at depth of 0-20 cm to compose a composite sample. Soil samples were identified, dried in the shade and sent to the laboratory of soil analysis for chemical and physical characterization, according to methodology described in Tedesco et al. (1995) and Kilmer and Alexander (1949), respectively. 


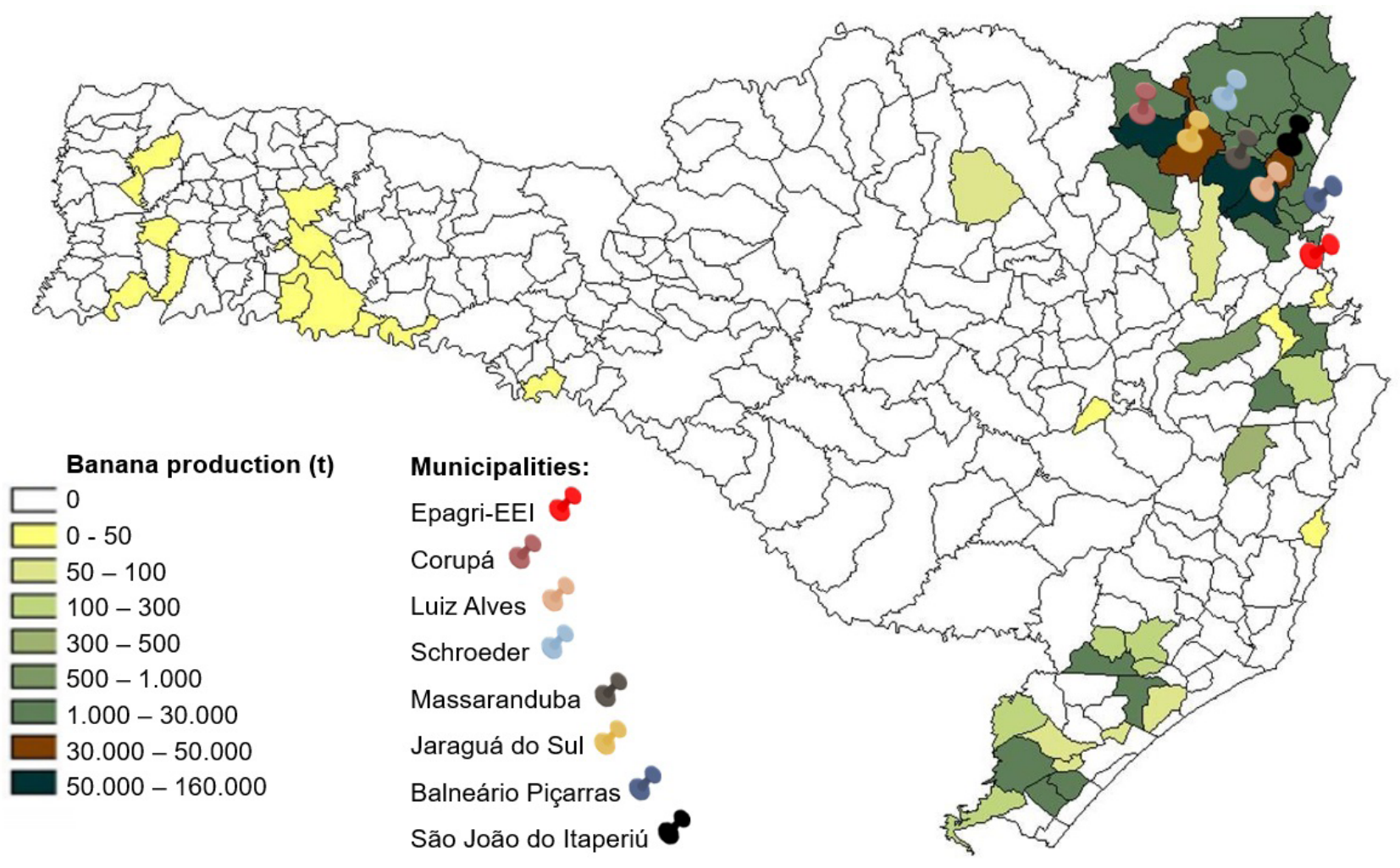

Figure 1. Banana production distribution in the state of Santa Catarina and identification of evaluated municipalities. Source: adapted from (CEPA, 2018).

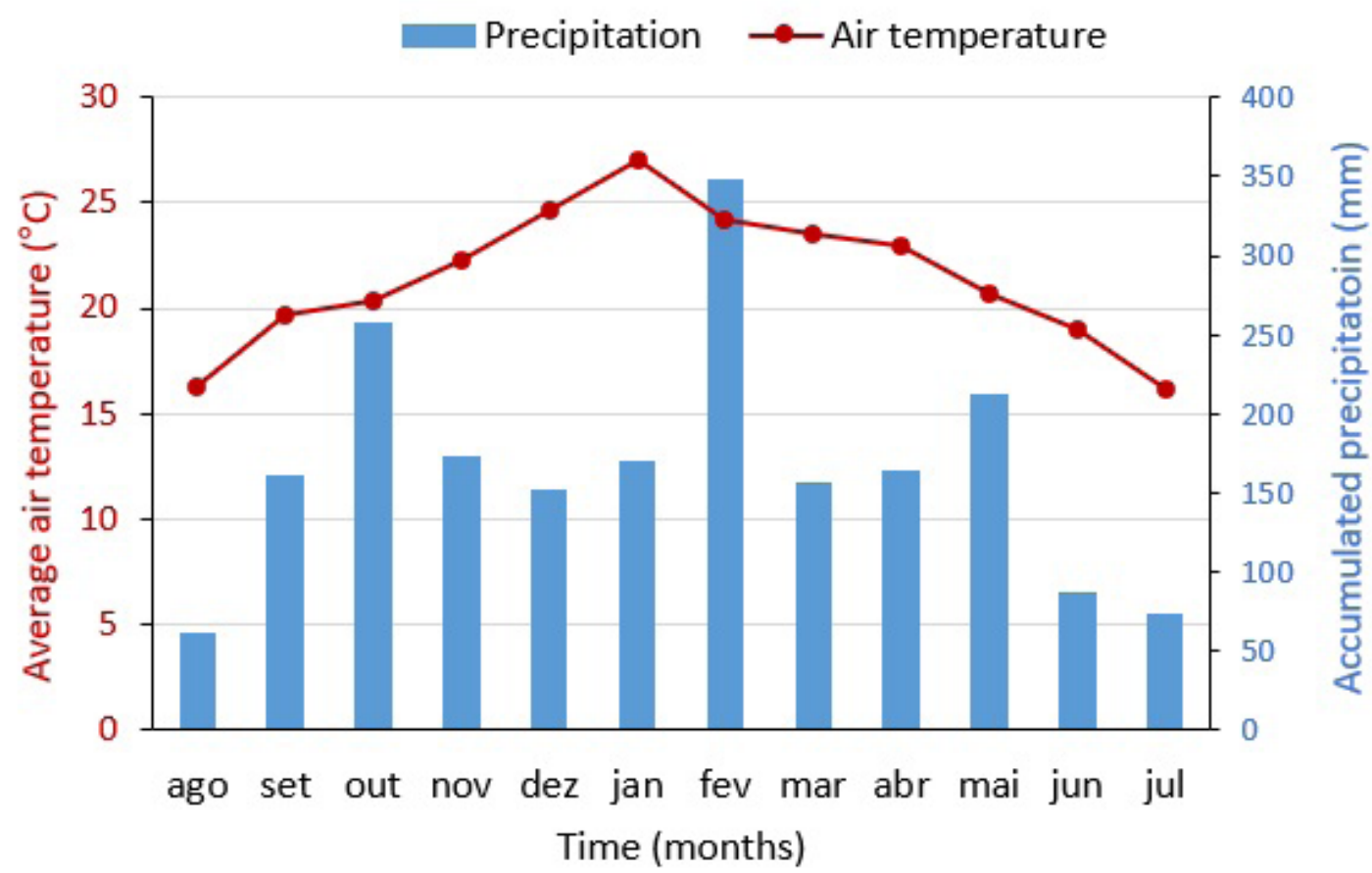

Figure 2. Accumulated precipitation and average air temperature from August 2018 to July 2019 in the study area. Data from Epagri/Ciram. 
Leaf sampling followed international standards according to Martin-Prével (1984). For this, samples of approximately $10 \mathrm{~cm}$ were collected from the central part of each side of the leaf blade of plants in the flowering stage (beginning of bunch emission) and the extremities of samples were discarded. Each sample consisted of material collected from 15 plants per area/orchard. Plants were identified to determine the weight of the bunch collected in the reference year in order to determine the productivity of the sampled area. Plant tissue samples (leaf) were dried in oven with air circulation at $60^{\circ} \mathrm{C}$ until constant weight and then sent to the laboratory of plant tissue analysis. Macro and micronutrient contents were quantified according to methods described by Malavolta et al. (1997).

The results of soil chemical analyses were interpreted according to Guimarães et al. (2020). Leaf analyses were interpreted using the Compositional Nutrient Diagnosis method - CND (PARENT and DAFIR, 1992), and sufficiency ranges were estimated based on CND standards for banana orchards in southern Brazil (GUIMARÃES et al., 2020). Descriptive analysis of data and frequency of stands were performed for the different sufficiency ranges. In addition, Pearson correlation analyses were performed between nutrient content in the soil, in banana leaves and bunch weight of 53 commercial banana orchards cultivated in Santa Catarina.

To estimate the maximum reachable yield, Potential Response Curves were used for the degree of Estimated Nutrient Balance (CRPENE), according to Galdino (2015). Regarding the quantification of possible losses and productivity reductions attributed or not to nutritional factors, the method proposed by Mendonça (2016) using coffee crop was used. The original method uses the balanced indexes of Kenworthy and the DRIS indexes; however, in the present study, they were replaced by the CND indexes.

The relative productivity values (y) were related by means of scatter plots $(y=f(x))$ to the respective CND indexes for each nutrient estimated based on standards proposed by Guimarães et al. (2020). In the obtained point cloud, pairs (xy) corresponding to the upper frontier of the relationship (frontier populations) were selected, which provide an optimal relationship between relative productivity and CND indexes.

Based on these equations, maximum productivity averages were estimated as a function of the CND indexes for each nutrient, which enabled estimating/quantifying the productivity reduction caused by nutritional factors. In addition, based on the Law of the minimum criterion, the lowest estimated relative productivity value among nutrients was selected, identifying nutrients that most limit productivity.

Then, the maximum relative productivity of $100 \%$ (value by which the banana orchard would be nutritionally balanced for all nutrients) was subtracted from the estimated relative productivity referring to the most limiting nutrient, thus obtaining productivity loss associated with nutritional factors. To obtain productivity loss associated with non-nutritional factors, the estimated relative productivity value of the analyzed banana orchard was subtracted from the observed relative productivity (obtained in the field), according to Mendonça (2016).

Nutritional Limitation $(\downarrow L N): \mathrm{Y}_{\text {maximum }}-\mathrm{Y}_{\text {reachable }}$

Non-nutritional Limitation $(\downarrow L \tilde{N N})$ : $\mathrm{Y}_{\text {reachable }}-\mathrm{Y}_{\text {observed }}$

For example, considering the hypothetical situation where: $100 \%$ corresponds to maximum productivity for the nutritionally balanced banana crop for all nutrients; $70 \%$ corresponds to maximum productivity reachable by the banana crop for the nutrient that most limits productivity based on the Law of the minimum criterion and $50 \%$ corresponds to productivity observed in the field.

Nutritional Limitation $(\downarrow$ LN): $100-70=30 \%$

Non-nutritional Limitation ( $\downarrow \mathrm{LN} N$ ): $70-50=20 \%$

It could be observed that values of 30 and $20 \%$ correspond to productivity losses due to nutritional and non-nutritional factors, respectively.

Finally, Principal Component Analysis was carried out, relating the nutrient contents of the banana leaf collected in two sampling periods to evaluate the edaphoclimatic effect on the nutritional status of banana trees.

\section{Results and discussion}

The chemical soil parameters of commercial areas under study are presented in table 1. These municipalities present clay content variation between 23 and $42 \%$, ranging from medium to clayey texture, with predominance of clayey soils. The $\mathrm{pH}$ values ranged from 4.2 to 6.5. According to Guimarães et al. (2020), in $65 \%$ of areas, there is predominance of acidic soils, of this total, 57 and $8 \%$ of orchards have $\mathrm{pH}$ values lower than 5.5 classified as "low" and "very low", respectively (Table 2). 
Table 1. Minimum, average, maximum values, standard deviation of the mean (S.D.) and coefficient of variation (C.V.) of the chemical soil parameters of commercial banana orchards of Santa Catarina $(n=53)$.

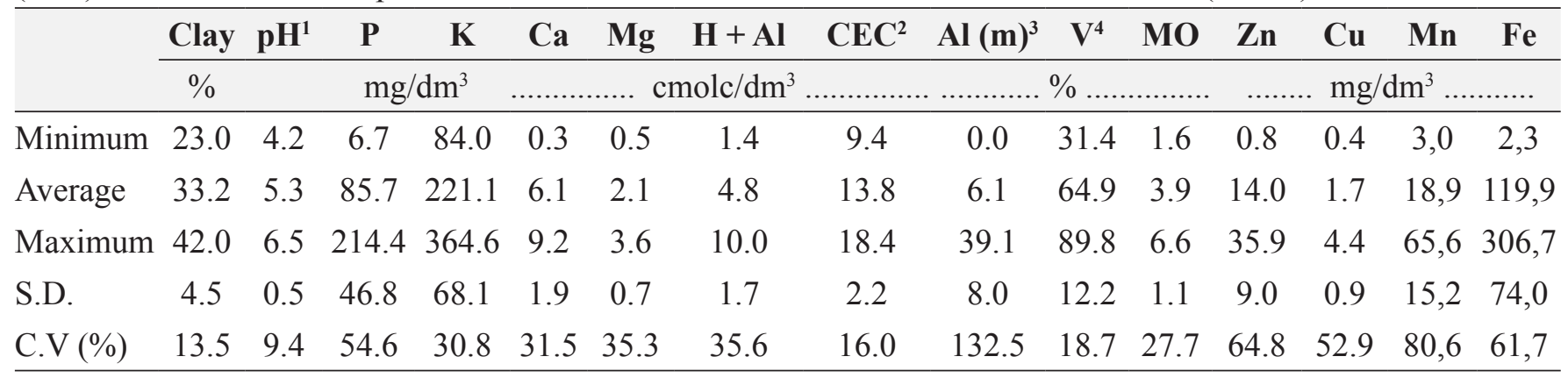

${ }^{1} \mathrm{pH}$ in water; ${ }^{2} \mathrm{Cation}$ Exchange Capacity at $\mathrm{pH} 7 ;{ }^{3}$ Aluminum saturation; ${ }^{4}$ Base saturation.

Table 2. Frequency of evaluated orchards $(n=53)$ in relation to the classification of soil chemical parameters.

\begin{tabular}{|c|c|c|c|c|c|c|c|c|c|c|c|c|}
\hline \multirow{2}{*}{ Class } & $\mathrm{pH}^{1}$ & $\mathbf{P}$ & $\mathbf{K}$ & MO & $\mathrm{Ca}$ & $\mathrm{Mg}$ & $\mathrm{CEC}^{2}$ & $\mathbf{V}^{3}$ & Zn & $\mathrm{Cu}$ & Mn & $\mathbf{F e}$ \\
\hline & \multicolumn{12}{|c|}{ 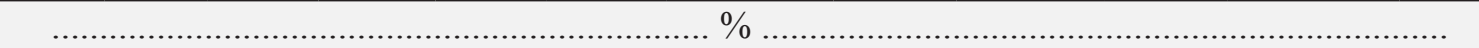 } \\
\hline Very low & 8 & 0 & 0 & - & 2 & 0 & 0 & 15 & 0 & 0 & 11 & 2 \\
\hline Low & 57 & 4 & 0 & 8 & 9 & 6 & 68 & 43 & 2 & 2 & 43 & 4 \\
\hline Average & 34 & 2 & 2 & 75 & 42 & 15 & 32 & 34 & 0 & 17 & 28 & 0 \\
\hline High & 2 & 9 & 34 & 17 & 47 & 79 & 0 & 8 & 34 & 72 & 17 & 4 \\
\hline Very high & - & 85 & 64 & - & - & - & - & - & 64 & 9 & 0 & 91 \\
\hline
\end{tabular}

${ }^{1} \mathrm{pH}$ in water; ${ }^{2}$ Cation Exchange Capacity at $\mathrm{pH} 7 ;{ }^{3}$ Base saturation.

Likewise, it is possible to observe variability in the base saturation "V", in which $58 \%$ of orchards are classified as low and very low $(\mathrm{V}<70 \%)$, requiring actions to correct acidity (Table 2 ). On the other hand, $42 \%$ of orchards have "V" above 70\%, which is recommended for banana cultivation. Although most orchards require liming, most of them have high soil $\mathrm{Ca}$ and $\mathrm{Mg}$ levels (Table 2). The need for liming is justified to correct acidity and neutralize exchangeable aluminum (reduce Al saturation), and not to supply $\mathrm{Ca}$ and $\mathrm{Mg}$ to the soil.

Organic matter (OM) and cation exchange capacity (CEC) presented "average" and "low" values, respectively, for most orchards (Table 2). Practices and management that promote $\mathrm{OM}$ increase and maintenance are always recommended, considering the importance of this parameter for soil biology and its positive impact on physical and chemical properties, including increase in CEC. Weed control with the use of herbicides exposes the soil surface, making it more susceptible to erosion, which is one of the main factors responsible for OM losses. On the other hand, the application of organic compounds as source of nutrients and especially the use of cover crops are the main strategies recommended to maintain or increase OM content in the soil. There is direct correlation between soil OM content and CEC value. Thus, management practices that promote increases in $\mathrm{OM}$ also promote increases in soil CEC.
The levels of soil micronutrients showed variability among evaluated orchards. This variation can be attributed to the application of supplies such as organic or mineral fertilizers and fungicides in different amounts in banana orchards. In general, orchards presented high $\mathrm{Zn}, \mathrm{Cu}$ and $\mathrm{Fe}$ levels, demonstrating satisfactory levels for these micronutrients. However, they had low Mn contents.

P contents ranged from 6.7 to $214.4 \mathrm{mg} \mathrm{dm}^{-3}$ (Table 1), with predominance of $85 \%$ of orchards classified as "very high" (Table 2), according to Guimarães et al. (2020). Soils with clay contents between 21 and $40 \%$ (most soils evaluated in this study) have critical P level of $18 \mathrm{mg} \mathrm{dm}^{-3}$. Thus, most banana orchards have excess $\mathrm{P}$ due to excessive doses in phosphorus fertilization and to $P$ accumulated by plants throughout the cycles and not exported at harvest time not accounted for in fertilization programs. In studies with 'Prata' banana for different yield classes, it was verified that, on average, $63.1 \%$ of all phosphorus is accumulated in non-exportable organs and return to the soil after harvesting (DEUS et al., 2020). 
Like $\mathrm{P}$, there is evidence of excessive application of potassium fertilizers in areas presenting critical soil $P$ level of $90 \mathrm{mg} \mathrm{dm}^{-3}$ for CEC values ranging from 7.5 to $15 \mathrm{cmol}_{\mathrm{c}} \mathrm{dm}^{-3}$ (GUIMARÃES et al., 2020). Soil K contents were classified as "high" or "very high" for most orchards (Table 2). This result suggests that the export of soil $\mathrm{K}_{2} \mathrm{O}$ provided by fruit harvesting is lower than its replacement through the application of fertilizers. As for deficiency, the excess of a certain nutrient in the soil may limit fruit production due to nutritional imbalance and, as a consequence, economic losses for producers due to costs with fertilizers and possible environmental impacts.
Descriptive analysis of productivity and macro and micronutrient content in the leaf tissue of the 53 sampled orchards are shown in table 3. Productivity had normal distribution, with values ranging from 19 to $72 \mathrm{t}$ $\mathrm{ha}^{-1}$ year $^{-1}$. In addition to nutritional factors, this variability in productivity can be attributed both to the type of cultivar used, considering that different representatives of the 'Cavendish' subgroup ('Nanica', 'Nanicão', 'Grand Naine' and 'Williams') are cultivated, and to other factors related to disease and pest control, soil management, plant density, orchard age, soil type, light intensity and soil water availability. The average productivity of orchards was $42 \mathrm{tha}^{-1}$ year-1 $^{-1}$ (Table 3), higher than the state average of $28.8 \mathrm{t} \mathrm{ha}^{-1}$ year-1 $^{-1}$ (CEPA, 2018).

Table 3. Minimum, average, maximum values, standard deviation of the mean (S.D.) and coefficient of variation (C.V) of the nutrient content of banana leaves and productivity of 'Cavendish' banana harvested in commercial orchards of Santa Catarina $(\mathrm{n}=53)$.

\begin{tabular}{|c|c|c|c|c|c|c|c|c|c|c|c|c|}
\hline & $\mathbf{N}$ & $\mathbf{P}$ & $\mathbf{K}$ & $\mathbf{C a}$ & Mg & $\mathbf{S}$ & $\mathbf{F e}$ & Mn & Zn & $\mathbf{C u}$ & B & Productivity \\
\hline & \multicolumn{11}{|c|}{. } & t/ha/year \\
\hline Minimum & 16.4 & 2.0 & 48.8 & 4.6 & 2.7 & 1.2 & 49.4 & 63.4 & 10.2 & 0.9 & 8.7 & 18.9 \\
\hline Average & 22.3 & 2.3 & 64.1 & 8.2 & 3.4 & 1.7 & 131.0 & 442.6 & 26.1 & 5.7 & 17.9 & 42.5 \\
\hline Maximum & 27.3 & 2.7 & 79.6 & 12.4 & 4.4 & 2.5 & 527.8 & 1143.6 & 46.7 & 11.5 & 37.5 & 71.8 \\
\hline S.D. & 2.9 & 0.2 & 7.5 & 1.9 & 0.4 & 0.3 & 75.4 & 296.3 & 10.5 & 2.6 & 9.6 & 11.2 \\
\hline C.V $(\%)$ & 13.0 & 6.7 & 11.7 & 23.0 & 11.4 & 15.1 & 57.5 & 66.9 & 40.2 & 46.2 & 54.0 & 26.4 \\
\hline
\end{tabular}

The levels of micronutrients in leaf tissues showed greater variations compared to those of macronutrients. This result can be attributed to the greater variation in the levels of micronutrients available in the soil. In addition, the concentration of these elements in banana leaf tissues undergoes greater variations during the collection period of leaf samples.

Most evaluated banana orchards presented $\mathrm{Fe}$ and $\mathrm{Cu}$ deficiency (Figure 3) according to the nutrient sufficiency range in banana leaves of the 'Cavendish' subgroup for the state of Santa Catarina (GUIMARÃES et al., 2020), despite the majority of orchards present levels of these nutrients in the soil classified as "high" or "very high". Similarly, B was deficient in $43 \%$ of orchards, while $\mathrm{Mn}$ and $\mathrm{Zn}$ are at adequate levels or in excess in most orchards (Figure 3). It is noteworthy that the presence or high concentrations of a given nutrient in the soil is no guarantee that the plant will have its nutritional requirements met. The supply of this nutrient to the plant is determined by the soil-plant-atmosphere relationship and not just by its presence in the soil. Soil is a complex and heterogeneous environment influenced by several factors such as $\mathrm{pH}$, interaction between nutrients, competitive uptake and edaphoclimatic factors that can influence the uptake of nutrients by plants.
For $\mathrm{Ca}, \mathrm{Mg}$ and $\mathrm{S}$ contents in the leaf tissue, most orchards are at adequate levels or in excess. In relation to $\mathrm{N}$, there was proportional distribution among orchards, in which 30,38 and $32 \%$ presented deficiency, balance and excess, respectively (Figure 3 ). On the other hand, 74 and $91 \%$ of orchards had excess $\mathrm{P}$ and $\mathrm{K}$, respectively, in the leaf tissue, according to the sufficiency range. These results reflect the high levels of these nutrients in soil (Table 2), which can intensify the nutritional imbalance of banana trees.

There was correlation between chemical soil attributes of soil, leaf and productivity as shown in Table 4. Soil OM was positively correlated with $\mathrm{N}$ and $\mathrm{S}$ contents in banana leaves. This result is expected given the importance of soil OM as sources of these nutrients after mineralization. On the other hand, soil OM was negatively correlated with $\mathrm{Ca}$ content in banana leaves (Ca_leaf). In part, this fact occurred due to the predominant acidity of soils under study. For these conditions, the predominance of $\mathrm{N}$ in the soil in the form of ammonium (ROSOLEM et al., 2003) negatively affects the absorption of ions such as $\mathrm{Ca}$ (HOLZSCHUH et. al., 2011; RIBEIRO et. al., 2012). 


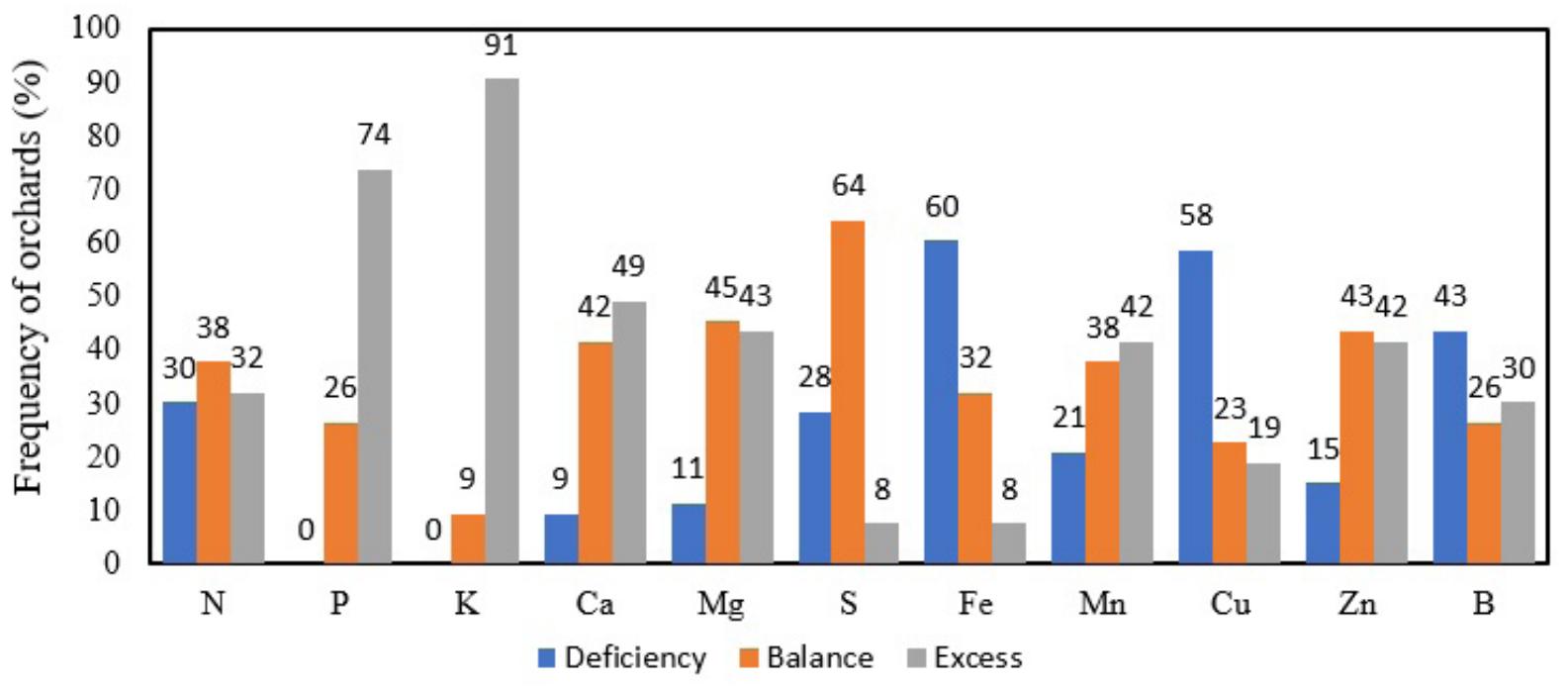

Figure 3. Frequency of orchards evaluated with nutrient deficiency, balance or excess according to the new nutrient sufficiency ranges in banana leaves of the 'Cavendish' subgroup for the state of Santa Catarina.

Table 4. Pearson correlation matrix between nutrient content in soil, banana leaf and bunch weight of 53 commercial banana orchards cultivated in Santa Catarina.

\begin{tabular}{|c|c|c|c|c|c|c|c|c|c|c|c|}
\hline Variables & S P_soil & K_soil & Ca_soil & Mg_soil & N_leaf & $P_{-}$leaf & $K_{-}$leaf & Ca_leaf & Mg_leaf & $S_{-}$leaf & $\begin{array}{l}\text { Bunch } \\
\text { weight }\end{array}$ \\
\hline $\mathrm{OM}$ & 0.055 & -0.079 & -0.136 & 0.012 & $0.338^{1}$ & 0.096 & 0.104 & -0.338 & -0.025 & 0,440 & $-0,181$ \\
\hline P_soil & & 0.503 & 0.395 & 0.136 & -0.063 & 0.260 & 0.304 & -0.083 & -0.180 & 0,049 & 0,434 \\
\hline K_soil & & & 0.300 & 0.311 & 0.011 & -0.032 & 0.219 & -0.105 & -0.198 & $-0,192$ & 0,357 \\
\hline $\mathrm{Ca}$ _soil & & & & 0.570 & 0.006 & 0.104 & 0.221 & 0.206 & 0.094 & 0,129 & 0,292 \\
\hline Mg_soil & & & & & -0.083 & 0.148 & 0.094 & 0.052 & 0.300 & 0,037 & 0,035 \\
\hline N_leaf & & & & & & -0.158 & 0.463 & -0.475 & -0.116 & 0,481 & $-0,051$ \\
\hline$P_{-}$leaf & & & & & & & 0.224 & 0.184 & 0.036 & 0,139 & $\mathbf{0 , 3 3 7}$ \\
\hline K_leaf & & & & & & & & -0.460 & -0.346 & 0,276 & 0,364 \\
\hline Ca_leaf & & & & & & & & & 0.435 & $-0,273$ & $-0,085$ \\
\hline $\mathrm{Mg}_{-}$leaf & & & & & & & & & & $-0,079$ & $-0,269$ \\
\hline S_leaf & & & & & & & & & & & 0,020 \\
\hline
\end{tabular}

${ }^{1}$ Values in bold are different from 0 with significance level of $\alpha=0.05$.

Positive correlations between $\mathrm{P}$ _soil with $\mathrm{K}$ _soil and $\mathrm{K}$ leaf can be attributed to the application of formulated fertilizers containing $\mathrm{P}_{2} \mathrm{O}_{5}$ and $\mathrm{K}_{2} \mathrm{O}$ in their composition. Furthermore, positive correlation was observed between $\mathrm{P}_{-}$soil and $\mathrm{Ca}$ _soil, showing the importance of liming in correcting soil acidity and, consequently, greater $\mathrm{P}$ availability, in addition to the regular use of fertilizers such as simple superphosphate, which is source of $\mathrm{P}$ and $\mathrm{Ca}$. However, the increase in soil $\mathrm{P}$ and $\mathrm{K}$ did not increase $\mathrm{P}$ and $\mathrm{K}$, respectively, in banana leaf in the same proportion. This result suggests that levels of these nutrients in the soil above requirements (higher values of the "very high" class) do not guarantee proportional increases in absorption, according to the law of decreasing increments.
The positive correlations observed between $\mathrm{K} \_$soil with $\mathrm{Ca}$ _soil and $\mathrm{Mg}$ _soil may be related to the process of building soil fertility, characterized by successive fertilizer applications (such as potassium sources) accompanied by periodic lime applications to correct soil acidity and provide $\mathrm{Ca}$ and $\mathrm{Mg}$ to plants. Among the most important correlations, the positive correlation between soil P, K and Ca contents and bunch weight stands out. Likewise, $\mathrm{P}_{\text {_leaf }}$ and $\mathrm{K}$ leaf contents were also positively correlated with bunch weight. This result highlights the importance of these macronutrients in banana production. 
The negative correlations between $\mathrm{K}$ leaf with $\mathrm{Ca} \_$leaf and $\mathrm{Mg}$ _ leaf were also evident. The high soil $\mathrm{K}$ contents, with values of up to $364.6 \mathrm{mg} \mathrm{dm}^{-3}$ (Table 1) can reduce $\mathrm{Ca}$ and $\mathrm{Mg}$ absorption by banana trees due to competition (antagonism) between these cations for the same absorption channel (NATALE and ROZANE, 2018). Thus, even though $K \_$soil and $K$ leaf are positively correlated with banana production, excess potassium can intensify $\mathrm{Ca}$ and $\mathrm{Mg}$ deficiencies in bananas and contribute to nutritional imbalance. It is worth highlighting the negative correlation between N_leaf and Ca_leaf contents, which is possibly related to competitive inhibition during $\mathrm{NH}_{4}^{+}$and $\mathrm{Ca}^{2+}$ uptake by plants. Furthermore, the different characteristics related to mobility (absorption, translocation and remobilization) of these cations in relation to the soil-plant system can further contrast the contents of these nutrients in plants, according to climatic factors such as soil water availability and temperature.
This study was carried out under real field conditions in commercial orchards, with productivity resulting from interactions of different nutritional and non-nutritional factors. The frontier technique was applied (WEBB, 1972) and equations were adjusted based on the relative productivity ratio as a function of CND indexes of macro and micronutrients (Table 5).

Table 5. Adjusted equations for the relationship between relative productivity (y) of the frontier population as a function of the CND (x) indexes of macro and micronutrients.

\begin{tabular}{cccc}
\hline Nutrient & Equation & $\mathbf{R}^{2}$ & Number of data \\
\hline $\mathrm{N}$ & $\mathrm{y}=-6.176 \mathrm{x}^{2}+0.868 \mathrm{x}+100.25$ & 0.92 & 11 \\
$\mathrm{P}$ & $\mathrm{y}=-6.687 \mathrm{x}^{2}-0.836 \mathrm{x}+100.05$ & 0.89 & 11 \\
$\mathrm{~K}$ & $\mathrm{y}=-5.210 \mathrm{x}^{2}-0.941 \mathrm{x}+100.71$ & 0.92 & 12 \\
$\mathrm{Ca}$ & $\mathrm{y}=-9.144 \mathrm{x}^{2}+2.825 \mathrm{x}+100.43$ & 0.92 & 14 \\
$\mathrm{Mg}$ & $\mathrm{y}=-6.297 \mathrm{x}^{2}+2.155 \mathrm{x}+100.77$ & 0.95 & 12 \\
$\mathrm{~S}$ & $\mathrm{y}=-8.239 \mathrm{x}^{2}-0.689 \mathrm{x}+101.84$ & 0.94 & 17 \\
$\mathrm{Fe}$ & $\mathrm{y}=-10.314 \mathrm{x}^{2}+6.644 \mathrm{x}+101.29$ & 0.88 & 13 \\
$\mathrm{Mn}$ & $\mathrm{y}=-12.385 \mathrm{x}^{2}+4.174 \mathrm{x}+100.21$ & 0.89 & 16 \\
$\mathrm{Cu}$ & $\mathrm{y}=-5.907 \mathrm{x}^{2}-4.301 \mathrm{x}+99.96$ & 0.91 & 10 \\
$\mathrm{Zn}$ & $\mathrm{y}=-5.760 \mathrm{x}^{2}-5.928 \mathrm{x}+100.39$ & 0.80 & 13 \\
$\mathrm{~B}$ & $\mathrm{y}=-8.976 \mathrm{x}^{2}+2.309 \mathrm{x}+96.54$ & 0.95 & 13 \\
$\mathrm{R}^{1}$ & $\mathrm{y}=-3.993 \mathrm{x}^{2}+0.670 \mathrm{x}+94.76$ & 0.89 & 11 \\
\hline
\end{tabular}

${ }^{1}$ Represents the sum of all other elements not measured in the plant tissue analysis.

The CND indexes for each nutrient were entered into the equations to estimate productivity (Table 6). These values represent the maximum reachable productivity of banana trees if there were no non-nutritional limitations (e.g., cold, water deficit, diseases etc.), considering only nutritional factors. Thus, for each municipality, it was possible to observe which nutrients are more limiting to productivity. 
Table 6. Estimated maximum productivity averages as a function of CND indexes for each nutrient and reduced productivity of banana plantations in Santa Catarina due to nutritional and non-nutritional factors.

\begin{tabular}{|c|c|c|c|c|c|c|c|c|c|c|c|c|c|c|c|}
\hline \multirow[t]{2}{*}{ Municipalities } & $\mathbf{N}$ & $\mathbf{P}$ & $\mathbf{K}$ & $\mathbf{C a}$ & $\begin{array}{c}- \text { Max } \\
\mathbf{M g}\end{array}$ & \multirow[t]{2}{*}{$\begin{array}{c}1 \mathrm{mu} \\
\mathbf{S}\end{array}$} & $\mathbf{F e}$ & Mn & \multirow[t]{2}{*}{$\mathbf{C u}$} & \multirow[t]{2}{*}{$\mathbf{Z n}$} & \multirow[t]{2}{*}{ B } & \multirow[t]{2}{*}{$\mathbf{R}^{1}$} & $Y_{\text {obs. }}{ }^{2}$ & \multicolumn{2}{|c|}{$\downarrow \mathbf{L} \mathbf{N}^{3} \downarrow \mathbf{L} \mathbf{N} \mathbf{N} 4$} \\
\hline & & & & & & & &..$\%$ & & & & & & & \\
\hline Balneário Piçarras & 89.6 & 91.8 & 92.9 & 87.3 & 93.8 & 95.6 & 66.5 & 91.5 & 95.8 & 67.8 & 80.3 & 84.7 & 74.6 & 45.3 & 19.4 \\
\hline Corupá & 70.1 & 97.3 & 96.6 & 91.9 & 92.2 & 93.1 & 83.2 & 82.5 & 87.8 & 89.7 & 81.1 & 71.8 & 51.3 & 50.3 & 17.7 \\
\hline Jaraguá do sul & 96.2 & 94.9 & 95.5 & 99.0 & 87.9 & 94.7 & 97.0 & $86.5^{\circ}$ & 79.0 & 98.7 & 84.4 & 78.2 & 54.4 & 35.8 & 23.5 \\
\hline Luiz Alves & 96.1 & 95.6 & 93.7 & 94.7 & 85.4 & 99.3 & 88.9 & 97.2 & 94.9 & 97.8 & 92.7 & 85.4 & 58.7 & 24.0 & 21.3 \\
\hline Massaranduba & 71.4 & 92.5 & 95.6 & 94.3 & 96.3 & 94.2 & 57.4 & 88.8 & 93.7 & 74.4 & 88.7 & 76.5 & 70.3 & 45.0 & 9.7 \\
\hline São João do Itaperiú & 80.6 & 95.4 & 96.1 & 85.6 & 94.8 & 94.8 & 85.0 & 87.2 & 97.8 & 72.3 & 79.0 & 80.0 & 59.3 & 42.1 & 34.1 \\
\hline Schroeder & 95.1 & 97.3 & 92.9 & 97.1 & 99.3 & 94.8 & 95.2 & 86.1 & 96.0 & 95.5 & 80.2 & 89.3 & 48.7 & 25.1 & 26.2 \\
\hline
\end{tabular}

Santa Catarina

$\begin{array}{lllllllllllllll}85.6 & 95.0 & 94.8 & 92.8 & 92.8 & 95.2 & 81.9 & 88.5 & 92.1 & 85.2 & 83.8 & 80.8 & 59.6 & 38.2 & 21.7\end{array}$

${ }^{1} \mathrm{R}$ : Maximum estimated productivity as a function of CND “IR" indexes. ${ }^{2} \mathrm{Y}_{\mathrm{obs}}$. : Relative productivity observed in the field; ${ }^{3} \downarrow \mathrm{LN}$ : reduction in relative productivity due to nutritional factors; ${ }^{4} \downarrow \mathrm{LNN}$ : reduction in relative productivity due to non-nutritional factors.

$\mathrm{N}$ is the macronutrient that most limited banana production in the state of Santa Catarina due to the application of doses below the demand for banana trees or doses out of balance with other nutrients (Table 6). Considering the nutritional limitation caused by $\mathrm{N}$, it could be inferred that the maximum average productivity for the state would be $85.6 \%$. In a hypothetical situation, if banana trees were with all contents nutritionally balanced, they could reach $100 \%$ productivity. Thus, it is possible to assume that productivity loss caused by $\mathrm{N}$ imbalance was $14.4 \%(100-85.6=14.4)$. However, as the average productivity observed in orchards was $59.6 \%$, it could be concluded that the reduction in productivity due to nonnutritional factors was $26 \%(85.6-59.6=26)$.

On the other hand, $\mathrm{P}$ and $\mathrm{K}$ levels in the plant demonstrate that these macronutrients are less limiting to productivity. However, there is evidence of excess of these nutrients both in soil (Table 2) and plant (Figure 3), which contributes to eventual imbalances. Likewise, $\mathrm{S}$ did not limit productivity, suggesting that its supply via OM mineralization or fertilizer application is meeting the plant's demand, which is observed by the high frequency of orchards classified with adequate leaf $\mathrm{S}$ contents $(64 \%)$ (Figure 3).

Regarding $\mathrm{Ca}$ and $\mathrm{Mg}$, only municipalities of Balneário Piçarras and São João do Itaperiú presented Ca limitations, while Jaraguá do Sul and Luiz Alves presented $\mathrm{Mg}$ limitations. This result highlights the importance of choosing the correct limestone to be applied in the orchard to correct eventual $\mathrm{Ca}$ or $\mathrm{Mg}$ deficiencies, in addition to correcting soil acidity. It is necessary to prioritize the application of correctives with higher magnesium carbonate levels in its composition in orchards with $\mathrm{Mg}$ deficiency and $\mathrm{Ca} / \mathrm{Mg}$ molar ratio greater than $4 / 1$.
Like N, micronutrients also limited banana productivity in the state of Santa Catarina. With the exception of $\mathrm{Cu}$, the other micronutrients provided the greatest productivity losses. Although $58 \%$ of orchards had $\mathrm{Cu}$ deficiency in leaf tissues (Figure 3), this micronutrient was not a limiting factor for production. This fact draws attention to the need for a multivariate and holistic evaluation considering not only an individualized diagnosis by nutrient, but its balance with others both in the soil and in the plant, as proposed by the CND method.

To assess productivity losses in the state and attribute them to nutritional and non-nutritional factors, the method proposed by Mendonça (2016) was adopted, originally used for coffee crop in the state of Minas Gerais. One of the main advantages of this technique/analysis is the possibility of assigning value to productivity losses, to the detriment of inadequate nutritional management, and recommend the use of nutrients in a more conscious and precise way.

The average productivity observed in the state of Santa Catarina is close to $60 \%$ of its potential, with emphasis on higher productivity in the municipalities of Balneário Piçarras (74.6\%) and Massaranduba (70.3\%), while the lowest productivity occurred in the municipality of Schroeder (48.7\%). Productivity reductions caused by " $\downarrow$ LN" nutritional factors varied according to municipality, with values between 24.0 to $50.3 \%$ and average of $38.2 \%$ for the state of Santa Catarina. Productivity reductions provided by " $\downarrow L \tilde{N} N$ " non-nutritional factors ranged from 9.7 to $34.1 \%$, with average of $21.7 \%$ (Table 6). Thus, it was found that nutritional factors provide greater productivity reductions compared to non-nutritional factors, as reported by Deus et al. (2018). 
In addition to basic care to carry out adequate collection and leaf sampling, it is necessary to consider the period in which collection was performed. Influence on the nutrient contents in banana leaves was observed as a function of the collection/sampling period (Figure 4). Only nutrients that showed significant variations were represented in the graph.
According to the principal components analysis, both contents and collection period showed different behaviors. Similarities were observed for $\mathrm{Ca}, \mathrm{Zn}, \mathrm{Cu}$ and $\mathrm{B}$, as well as for $\mathrm{N}, \mathrm{S}$ and $\mathrm{K}$ (Figure 4). P and $\mathrm{Mg}$ presented behavior different from the others. With regard to differences in the collection period, only the $\mathrm{Ca}, \mathrm{Zn}$, $\mathrm{Cu}$ and $\mathrm{B}$ group showed significant differences (Table 7). However, these differences did not impact production between these periods. These results corroborate those presented by Costa et al. (2019), who also observed similar variations in nutrient content in 'Grande Naine' banana leaves sampled during winter and summer.

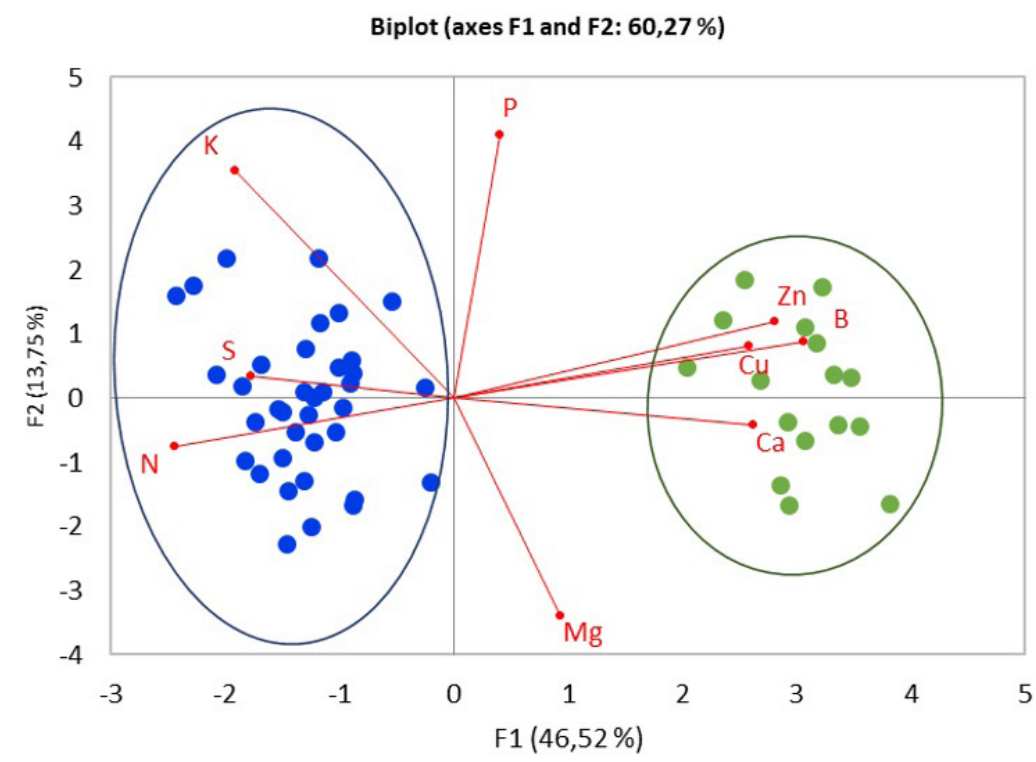

- Variables/nutrients Collections: • 2018/II • 2019/I

Figure 4. Analysis of principal components relating nutrient contents in banana leaves in two collection periods (September to December 2018 “2018/II” or January to April 2019 “2019/I”).

Table 7. Average nutrient contents in banana leaves collected from September to December 2018 "2018/II" or from January to April 2019 "2019/I” and production of bananas from plants sampled in the respective periods.

\begin{tabular}{|c|c|c|c|c|c|c|}
\hline Collection & $\mathbf{N}$ & $\mathbf{P}$ & $\mathbf{K}$ & Ca & Mg & $\mathbf{S}$ \\
\hline & & & $\mathrm{g} / \mathrm{k}$ & & & \\
\hline 2018/II & $23.6 \pm 2.0$ & $2.29 \pm 0.16$ & $66.6 \pm 6.6$ & $7.3 \pm 1.15$ & $3.3 \pm 0.39$ & $1.76 \pm 0.25$ \\
\hline 2019/I & $19.3 \pm 2.3$ & $2.34 \pm 0.15$ & $58.3 \pm 6.1$ & $10.4 \pm 1.38$ & $3.5 \pm 0.35$ & $1.47 \pm 0.08$ \\
\hline \multirow{2}{*}{ Collection } & $\mathbf{F e}$ & Mn & $\mathbf{Z n}$ & $\mathbf{C u}$ & B & Mean bunch weight \\
\hline & & & $\mathrm{mg} / \mathrm{k}$ & & & $\mathrm{kg}$ \\
\hline 2018/II & $142.9 \pm 79.8$ & $471.3 \pm 319$ & $20.1 \pm 3.3$ & $4.4 \pm 1.7$ & $11.8 \pm 2.0$ & $33.3 \pm 8.5$ \\
\hline 2019/I & $103.3 \pm 56.9$ & $376.0 \pm 228$ & $40.1 \pm 7.7$ & $8.8 \pm 1.7$ & $31.7 \pm 4.4$ & $33.3 \pm 9.8$ \\
\hline
\end{tabular}

Banana leaves sampled from September to December were emitted under conditions of less soil water availability and lower temperatures. These factors provide less mobility of nutrients in the soil and plants due to lower transpiration rates. On the other hand, leaves sampled between the months from January to April were emitted under more favorable conditions for the transport of nutrients in the soil, absorption and translocation in the plant. In addition, the latter were also more influenced by fertilization, which usually starts in the rainy season, compared to leaves issued from September to December. 
$\mathrm{K}$ and $\mathrm{P}$ ions are transported from the soil solution to plant roots preferentially by diffusion, while $\mathrm{N}, \mathrm{Ca}, \mathrm{Mg}$, $\mathrm{S}, \mathrm{Fe}, \mathrm{Zn}, \mathrm{Cu}$, and $\mathrm{B}$ ions are preferentially transported by mass flow (NOVAIS and MELLO, 2007). Thus, the absorption of nutrients transported by mass flow is considerably reduced in times of soil water deficit and lower transpiration rate. Furthermore, N, P, K and $\mathrm{Mg}$ are considered mobile in the plant, that is, they can be redistributed from old leaves to new leaves. $\mathrm{S}, \mathrm{Cu}, \mathrm{Fe}, \mathrm{Mn}$ and $\mathrm{Zn}$ are considered little mobile, while $\mathrm{Ca}$ and $\mathrm{B}$ are considered immobile (MARSCHNER, 1995).

The lower $\mathrm{Ca}, \mathrm{Zn}, \mathrm{Cu}$ and $\mathrm{B}$ concentrations in leaves collected in 2018/II can be attributed to lower absorption of these nutrients in this period, in addition to the low or absence of redistribution of these elements from old leaves to younger leaves. Although $\mathrm{N}, \mathrm{P}, \mathrm{K}$ and $\mathrm{Mg}$ absorption is also lower during this period, these nutrients can be more easily redistributed to new leaves in order to meet nutritional requirements. This result explains the frequent deficiencies, mainly related to $\mathrm{Ca}$ and $\mathrm{B}$, observed in commercial orchards in the first months of the rainy season (time when banana trees accelerate their development and leaf emission). In this case, deficiency may be due to climatic and physiological factors and not to the lack of the nutrient in the soil. In many cases, these nutritional deficiencies are momentary, considering that the new leaves emitted during the period of greater soil water availability and higher temperatures (for example: leaves sampled in 2019/I) can present high concentrations of these nutrients.

Therefore, it is evident that the collection period of leaf samples influences the nutritional status of banana trees. Standardizing the sampling period at the time of greatest bunch emission is recommended, which refers to the period of greatest plant development and, consequently, greater nutritional demand. This period usually occurs in the summer, between the months of December and March. Furthermore, the integration of leaf analysis with information from soil analysis for a more accurate diagnosis of the nutritional status and better understanding of the soil-plant-atmosphere system is of paramount importance.

\section{Conclusion}

Nutritional factors are the main limiting factors in the productivity of banana crops in the state of Santa Catarina, surpassing non-nutritional factors.

Liming and fertilization recommendations do not use tools such as soil and leaf analysis in most orchards, leading orchards to nutritional imbalances.

The most limiting nutrients to productivity in the state are N, Fe, Mn, Zn and B.

The average productivity observed for the state is $59.6 \%$ of its productive potential.
There are seasonal variations in leaf nutrient contents as a function of the collection period, and it is recommended to standardize this period.

\section{Acknowledgements}

The authors thank EPAGRI for funding this study. Thanks to the technical team at EEI, GRI and the associations of banana growers ABLA and ASBACO by collaboration in the conceptualization and data acquisition of this study.

\section{References}

ALVAREZ, C.E.; GARCÍA, V.; ROBLES, I.; DÍAZ, A. Inflence des caracterisques du sol sur lincidence de la Maladie de Panamá. Fruits, Les Ulis, v.36, n.1, p.71-81, 1981.

CEPA - Centro de Estudos de Safras e Mercados. Síntese anual da agricultura de Santa Catarina - 2017-2018. Florianópolis: Epagri/Cepa, 2018. 204p.

COSTA, L.G.A.F.; ROZANE, D.E.; SILVA, S.A.; OLIVEIRA, C.T.; PAVARIN, L.G.F.; SILVA, S.H.M.G. Seasonality in nutrient content of banana diagnostic leaf. Revista Brasileira de Fruticultura, Jaboticabal, v.41, n.4, p.e-151, 2019.

DEUS, J.A.L.; NEVES, J.C.L.; SOARES, I.; ALVAREZ, V.; V.H.; LIMA NETO, A.J.; ALBUQUERQUE, F.M.R.; SANTOS, L.L.; NATALE, W. Multivariate selection and classification of mathematical models to estimate dry matter partitioning in the fertigated Prata banana in the Northeast Brazil. Field Crops Research, Amsterdam, v.255, 107897, 2020.

DEUS, J.A.L.; NEVES, J.C.L.; CORRÊA, M.C.M.; PARENT, S.; NATALE, W.; PARENT, L.E. Balance design for robust foliar nutrient diagnosis of Pratabanana (Musa spp.). Scientific Reports, London, v.8, n.15040, 2018.

EMBRAPA-Empresa Brasileira de Pesquisa Agropecuária. Solos do Estado de Santa Catarina. Rio de Janeiro: Centro Nacional de Pesquisa de Solos, 2004. 745p. (Boletim técnico, 46)

FAOSTAT - Food and Agriculture Organization of The United Nations. Statistics Division. Rome, 2020. Disponível em: http://faostat3.fao.org/download/Q/QC/E. Acesso em: 05 maio 2020. 
FREITAS, A.S.; POZZA, E.A.; POZZA, A.A.A.; OLIVEIRA, M.G. F.; SILVA, H. R.; ROCHA, H. S.; GALVAO, H.R. Impact of nutritional deficiency on yellow Sigatoka of banana. Australasian Plant Pathology, Clayton, v.44, n.5, p.583-590, 2015.

GALDINO, M.P. Valores de referência e faixas de suficiência para avaliação do estado nutricional da cultura do eucalipto no Brasil. 2015. Tese (Doutorado em Solos e Nutrição de Plantas) - Universidade Federal de Viçosa, Viçosa, 2015.

GUIMARÃES, G.G.F.; DEUS, J.A.L.; ROZANE, D.E. Calagem, adubações e valores de referência de nutrientes na cultura da banana. In. BRUNETTO, G. et al. Atualização sobre calagem e adubação em frutíferas. Porto Alegre: Núcleo Regional Sul da Sociedade Brasileira de Ciência do Solo, 2020. 65-77 p.

HOFFMANN, R.B.; OLIVEIRA, F.H.T.; SOUZA, A.P.; GHEYI, H.R.; JÚNIOR, R.F.S. Acúmulo de matéria seca e de macronutrientes em cultivares de bananeira irrigada. Revista Brasileira de Fruticultura, Jaboticabal, v.32, n.1, p.268-275, 2010.

HOLZSCHUH, M.J.; BOHNEN, H.; ANGHINONI, I.; PIZZOLATO, T.M.; CARMONA, F.C.; CARLOS, F.S. Absorção de nutrientes e crescimento do arroz com suprimento combinado de amônio e nitrato. Revista Brasileira de Ciência do Solo, Viçosa, MG, v.35, n.4, p.1357-1366, 2011.

KILMER, V.J.; ALEXANDER, L.T. Methods of making mechanical analysis of soils. Soil Science, Madison, v.68, n.1, p.15-24. 1949.

LICHTEMBERG, L.A.; LICHTEMBERG, P.S.F. Avanços na bananicultura brasileira. Revista Brasileira de Fruticultura, Jaboticabal, v.33, n.esp., p.29-36, 2011.

LIMA NETO, A.J.; DEUS, J.A.L.; RODRIGUES FILHO, V.A.; NATALE, W.; PARENT, L.E. Nutrient diagnosis of fertigated "Prata" and "Cavendish" banana (Musa spp.) at plot-scale. Plants, Basel. v.9, n.11, p.1467, 2020.

MALAVOLTA, E.; VITTI, G. C.; OliVEIRA, S. A. Avaliação do estado nutricional das plantas: princípios e aplicações. 2.ed. Piracicaba: POTAFOS, 1997. 319 p.

MARSCHNER, H. Mineral nutrition of higher plants. London: Academic Press, 1995. 889 p.
MARTIN-PRÉVEL, P. Bananier. In: MARTIN-PRÉVEL, P.; GAGNARD, J.; GAUTIER, P. (ed.). L'analyse végétale dans le contrôle de l'alimentation des plantes tempérées et tropicales. Paris: Tec \& Doc, 1984. p.715751 .

MENDONÇA, L.P. Curvas de resposta potencial e faixas de suficiência nutricional para café arábica em Minas Gerais. 2016. Dissertação (Mestre emFitotecnia) - Universidade Federal de Viçosa, Viçosa, 2016.

NATALE, W.; ROZANE, D.E. Análise de solo, folhas e adubação de frutíferas. Registro: UNESP, Câmpus Experimental de Registro, 2018. p. 124.

NOVAIS, R.F.; MELLO, J.W.V. Relação solo-planta. In: NOVAIS, R.F.; ALVAREZ V., V.H.; BARROS, N.F.; FONTES, R.L.F.; CANTARUTTI, R.B.; NEVES, J.C.L. Fertilidade do solo. Viçosa (MG): Sociedade Brasileira de Ciência do Solo, 2007. p.276-374.

PARENT, L.E.; DAFIR, M.A. Theoretical concept of compositional nutrient diagnosis. Journal of American Society of Horticultural Science, Alexandria, v.117, n.2, p.239-242. 1992.

RIBEIRO, M.O.; BOECHAT, C.L.; CONCEIÇÃO, M.G.S.; MOREIRA, F.M.; RIBEIRO, L.O.; SANTOS, A.R. Efeito das interações entre os íons amônio e nitrato na fisiologia do crescimento do amendoinzeiro. Revista Ceres, Viçosa, MG, v.59, n.5, p.630-635, 2012.

ROSOLEM, C.A; FOLONI, J.S.S; OLIVEIRA, R.H. Dinâmica do nitrogênio no solo em razão da calagem e adubação nitrogenada, com palha na superfície. Pesquisa Agropecuária Brasileira, Brasília, DF, v.38, n.2, p.301309, 2003.

SILVA, J.T.A. DA; RODRIGUES, M.G.V. Avaliação nutricional, produção e incidência do mal-do-panamá em bananeira 'Prata-Anã' (AAB) adubada com K, no quarto ciclo. Revista Brasileira de Fruticultura, Jaboticabal, v.35, n.4, p.1170-1177, 2013.

TEDESCO, M.J.; GIANELlO, C.; BISSANI, C.A.; BOHNEN, H.; VOLKWEISS, S.J. Análise de solo, plantas e outros materiais. 2.ed. Porto Alegre: Universidade Federal do Rio Grande do Sul. 1995. 174p. (Boletim Técnico de Solos, 5).

WEBB, R. A. Use of boundary line in the analysis of biological data. Journal of Horticultural Science, Ashford, v.47, n.3, p.309-319, 1972. 